\title{
INVESTMENT OPPORTUNITY SET (IOS) BERBASIS PERTUMBUHAN PERUSAHAAN DAN KAITANNYA DENGAN UPAYA PENINGKATAN NILAI PERUSAHAAN
}

\author{
Eka Handriani \\ Fakultas Ekonomi dan Bisnis \\ Universitas Darul Ulum Islamic Centre Sudirman GUPPI \\ ekahandriani@gmail.com \\ Tjiptowati Endang Irianti \\ Fakultas Ekonomi dan Bisnis \\ Universitas Darul Ulum Islamic Centre Sudirman GUPPI \\ endang@yahoo.com
}

\begin{abstract}
This research aims to develop theoretical approach to complete the conceptual controversy regarding the research results on the investment policy and firm value. This research employs firm value, investment opportunity set (IOS), funding and dividend as variables. Dividends in the research proxied by dividend pay out ratio (DPR), funding proxied by DER and firm value indicated by Tobin's $q$, which are mediated by IOS. The sample are taken from 154 manufacturing company financial statements during 2010 to 2012. The data were tested using path analysis. The research found that dividend and funding policy positively influence IOS. Investment opportunity (IOS) positively influences the firm value. IOS was able to mediate the effect of dividends to the firm value, and also the influence of funding decisions to firm value.
\end{abstract}

Keywords: investment opportunity set (IOS), dividend pay out ratio (DPR), firm value

\section{PENDAHULUAN}

Tujuan operasional perusahaan secara umum adalah untuk memaksimalkan kekayaan dan kesejahteraan pemegang saham. Hal ini bisa dicapai dengan berbagai upaya yaitu melalui keputusan penggunaan profit untuk pembayaran deviden, kesempatan investasi atau investment opportunity set (IOS) dan kebijakan pendanaan.

Menurut Jiambalvo dan Rajgopal (2002), harga saham, IOS dan keputusan pendanaan mencerminkan nilai perusahaannya. Harga transaksi yang terjadi antara penjual dan pembeli berdasarkan nilai perusahaan ini sesungguhnya disebut nilai pasar perusahaan. Nilai pasar perusahaan ini yang nantinya akan memunculkan 
peluang-peluang investasi. Adanya peluang investasi dapat memberikan sinyal positif tentang pertumbuhan perusahaan di masa yang akan datang, sehingga dapat meningkatkan nilai perusahaan.

Dalam upaya peningkatan nilai perusahaan, diperlukan suatu kemampuan pengelolaan keuangan yang akurat, jika suatu keputusan keuangan diambil maka akan berdampak pada kondisi keuangan yang lain, hal ini akan berujung pada kondisi nilai perusahaan. Fungsi-fungsi pengelolaan keuangan menyangkut pengelolaan atas keputusan penting yang diambil perusahaan, antara lain keputusan investasi, pendanaan dan kebijakan dividen. Dalam upaya optimalisasi nilai perusahaan diperlukan suatu kombinasi dari ketiganya yang saling berhubungan satu dengan lainnya. Cerminan dari pengelolaan keuangan perusahaan yang dilakukan dengan baik adalah meningkatnya harga pasar sahamnya.

Myers (1977) berpendapat bahwa nilai perusahaan didasarkan atas dua elemen yaitu, pertama, aset riil yang dinilai secara independen dari peluang investasi masa depan perusahaan. Alasannya adalah ketika perusahaan memiliki aset riil seperti properti dan peralatan maka perusahaan dihadapkan pada sejumlah aktivitas yang dapat ditukarkan satu sama lain ketika aset riil rendah. Hal ini dilakukan untuk meminimalkan biaya agensi yang dapat timbul antara pemegang saham dan manajer (biaya yang berhubungan dengan tidak adanya penciptaan (discreation)). Kedua, real option (growth option) yang dinilai berdasarkan pilihan keputusan investasi masa depan perusahaan. Alasannya adalah ketika perusahaan memiliki risiko hutang, maka manajer bertindak atas nama shareholder untuk menolak investasi yang berpotensi meningkatkan nilai perusahaan dengan alasan akan menambah manfaat bagi debtholder. Hal ini akan mengakibatkan masalah under investment. Kemampuan perusahaan untuk dapat meningkatkan nilai perusahaan dapat diperoleh dari pemilihan serangkaian kesempatan investasi (investment opportunity set).

Investment opportunity set diharapkan dapat memediasi pengaruh antara dividend terhadap nilai perusahaan. Gap dalam penelitian ini adalah terdapat perbedaan pandangan tentang pengaruh kebijakan dividen terhadap nilai perusahaan. Hasil penelitian yang sejalan dengan pandangan pertama bahwa kebijakan dividend tidak berpengaruh terhadap nilai perusahaan yang didukung oleh teori dividend irrelevance (Miller dan Modigliani 1961). Penelitian yang sejalan dengan hal ini telah dilakukan oleh Black dan Scholes (1974), Petit (1974) serta Miller dan Scholes (1982). Hasil penelitian yang sejalan dengan pandangan kedua adalah kebijakan dividen berpengaruh terhadap nilai perusahaan yang didukung oleh teori bird in the hand (Gordon dan Litner (1963), Allen et al. (2000), Baker dan Wurger (2004), De Anggelo dan De Anggelo (2005), Brav et al. (2003) dan Amidu (2007)). Hasil penelitian ini diharapkan mengisi gap dengan memediasi variabel investment opportunity set untuk menduga adanya pengaruh yang signifikan antara kebijakan dividend dan nilai perusahaan. 
Studi mengenai efek kebijakan dividen terhadap nilai perusahaan ini didasarkan pada gap yang ada mengenai penelitian sebelumnya. Penelitian ini diharapkan dapat menjawab permasalahan mengenai bagaimana mengembangkan sebuah model teoretis untuk mengisi kesenjangan hasil penelitian empiris tentang kebijakan dividen terhadap nilai perusahaan pada industri manufaktur di Indonesia.

Penelitian ini bertujuan untuk menguji pengaruh pada nilai perusahaan sebagai mekanisme struktur modal dalam konteks Indonesia. Pertama, penelitian ini menguji pengaruh dividen terhadap kesempatan investasi (IOS). Ke-dua, penelitian ini menguji pengaruh kebijakan pendanaan terhadap kesempatan investasi (IOS). Ketiga penelitian ini menguji pengaruh kesempatan investasi (IOS) terhadap nilai perusahaan. Ke-empat, penelitian ini mengevaluasi kemungkinan variabel kesempatan investasi dalam memediasi kemampuan pembayaran dividen untuk meningkatkan nilai perusahaan serta pengaruh mediasi antara keputusan pendanaan untuk meningkatkan nilai perusahaan.

\section{KAJIAN TEORI DAN PENGEMBANGAN HIPOTESIS}

\section{Teori Keagenan}

Pada tahun 1776 Adam Smith meletakkan dasar tentang konsep organisasi yang efisien dengan mengenalkan teori division of labour yang mengharuskan dilakukannya spesialisasi fungsi agar organisasi perusahaan dapat mencapai tujuan secara lebih efisien. Hal ini telah memberikan perkembangan pada teori organisasi dan korporasi modern Marshal di tahun 1920, serta Berle dan Means pada tahun 1933. Teori ini menyatakan bahwa dalam suatu organisasi harus terdapat pemisahan yang tegas antara aktivitas pengendalian dengan aktivitas operasional, yaitu pemisahan antara board of directors sebagai representasi dari pemegang saham yang melakukan fungsi pengendalian atas operasional perusahaan dan board of management-CEO sebagai pihak yang menjalankan operasional perusahaan. Adam Smith berpendapat bahwa dengan memaksimalkan kepentingan diri sendiri maka setiap orang akan memberikan manfaat kepada masyarakat. Individu yang memaksimalkan laba dan kepentingan pribadinya secara otomatis akan membuat alokasi sumber daya sebaik mungkin. Perkembangan dan transformasi etika kapitalis ini memunculkan paradigma agency theory, yaitu bagaimana individu atau kelompok yang terlibat dalam pengelolaan suatu organisasi berperilaku dalam mencapai sasaran (memaksimalkan nilai) bersinggungan dengan kepentingan yang memunculkan konflik organisasi (Eskandari 2012).

Berle dan Means (1933) dalam karya penelitiannya yang tidak dipublikasikan, secara eksplisit menyatakan tentang pemisahan kepemilikan (ownership) dan pengendalian (control) perusahaan, sehingga distribusi kepemilikan saham dalam perusahaan menjadi suatu hal yang penting. Ketika pengendalian perusahaan tidak lagi dilakukan oleh pemilik tetapi diserahkan kepada pihak lain 
untuk mengelola sumber daya perusahaan, maka permasalahan yang muncul adalah potensi konflik dalam hubungan antara pemilik (principals) dengan pengelola (agent) yang sering disebut dengan masalah keagenan (agency problem). Hubungan keagenan digambarkan sebagai hubungan yang timbul karena adanya kontrak yang ditetapkan antara prinsipal yang menggunakan agen untuk memberikan jasanya bagi kepentingan prinsipal (Jensen dan Meckling 1976). Jensen dan Meckling (1976) menyatakan bahwa agency problem akan terjadi bila proporsi kepemilikan manajer atas saham perusahaan kurang dari 100 persen sehingga manajer cenderung bertindak untuk kepentingan dirinya dan tidak bertujuan untuk memaksimalkan nilai perusahaan dalam pengambilan keputusan pendanaan.

Jensen (1988) menjelaskan bahwa konflik kepentingan manajer dengan kepentingan pemegang saham terjadi dengan asumsi pemilik (shareholders) dan agen (manager) masing-masing menginginkan return yang tinggi terhadap proyekproyek investasi tetapi dengan kepentingan yang berbeda terhadap risiko. Perbedaan terhadap risiko dijelaskan oleh Amihud dan Lev (1981) bahwa shareholders lebih berkepentingan terhadap risiko sistematis, sedangkan manajer lebih berkepentingan terhadap risiko tidak sistematis. Pawlina dan Renneboog (2005) menjelaskan bahwa konflik ini terjadi dalam perusahaan dengan free cash flows yang besar karena manajer akan melakukan investasi atas kelebihan kas yang diperoleh dari sumber dana internal ini untuk mengoptimalkan keuntungan pribadinya dengan tidak melakukan pembayaran dividen tunai kepada pemegang saham.

\section{Teori Kesempatan Investasi (Investment Opportunity Set)}

Pengertian investasi secara umum adalah kegiatan menanamkan modal yang dilakukan oleh investor pada suatu aset tertentu untuk mendapatkan pengembalian yang lebih besar dibandingkan yang dikorbankan. Aharony (2010) mendefinisikan investasi sebagai komitmen saat ini dalam uang, untuk suatu periode waktu dengan tujuan untuk mendapatkan pembayaran di masa depan yang akan mengkompensasikan investor untuk: (1) waktu ketika dana digunakan, (2) tingkat inflasi yang diharapkan dan (3) ketidakpastian atas pembayaran di masa depan.

Investor dalam pemaknaannya bisa merupakan individu, perusahaan atau pemerintah. Dharmapala et al. (2008) menyebutkan investasi adalah komitmen saat ini atas uang atau sumber daya lain dengan harapan mendapatkan keuntungan di masa depan.

Untuk melakukan investasi, perusahaan membutuhkan kesempatan, suatu rencana atau proyek yang bisa dipilih untuk mewujudkan tujuannya untuk menghasilkan lebih banyak uang. Kumpulan kesempatan investasi (investment opportunity set) adalah pilihan-pilihan investasi yang tersedia bagi individu atau perusahaan yang dapat dilakukankan perusahaan. Kesempatan investasi yang dimiliki perusahaan memengaruhi cara pandang manajer, pemilik, investor dan kreditor tentang nilai perusahaan. Miller dan Modigliani (1961) membagi nilai 
perusahaan (value of the firm) berdasarkan present value dari pendapatan yang dihasilkan aset yang dimiliki (asset in place) dan kesempatan membuat tambahan investasi dalam aset riil yang akan menghasilkan tingkat pengembalian yang lebih dari tingkat pengembalian normal.

Smith dan Watts (1992) menjelaskan bahwa IOS adalah komponen nilai perusahaan yang berasal dari pilihan untuk membuat investasi di masa depan. Penelitian Kallapur dan Trombley (1999) menyatakan bahwa IOS perusahaan memengaruhi cara perusahaan dinilai oleh manajer, pemilik, investor dan kreditor. Sementara Kole dan Lehn (1991) menjelaskan bahwa nilai IOS bergantung pada pengeluaran yang oleh manajemen masa depan dan saat ini diharapkan dapat memberikan pengembalian yang lebih besar daripada biaya modal. Bahkan terkait dengan pergerakan harga saham, Hanna dan Palepu (1999) menyatakan bahwa IOS menjadi faktor yang dominan. Dari definisi di atas, dapat diinterpretasikan bahwa IOS berisi dua istilah. Pertama, IOS merupakan keputusan investasi oleh perusahaan untuk memberikan pertumbuhan positif, sehingga IOS dianggap sebagai prospek pertumbuhan. Kedua, IOS adalah kemampuan perusahaan untuk menentukan jenis investasi yang akan dilakukan. Bagi perusahaan yang tidak mampu memilih investasi yang tepat, maka pengeluaran akan lebih tinggi dari nilai kesempatan yang hilang. Oleh karena itu, dapat disimpulkan bahwa IOS adalah hubungan antara pengeluaran saat ini dan nilai masa depan/pengembalian/prospek sebagai akibat dari keputusan investasi untuk menghasilkan nilai pemegang saham.

Pilihan investasi dimasa mendatang tidak semata-mata ditunjukkan oleh adanya proyek-proyek yang didukung oleh kegiatan riset dan pengembangan (Gaver dan Gaver 1993). Tetapi juga ditunjukkan oleh kemampuan perusahaan yang lebih dalam mengeksploitasi kesempatan untuk mengambil keuntungan dibandingkan perusahaan lain dalam kelompok industrinya. Kemampuan perusahaan yang tinggi ini bersifat tidak dapat diobservasi (unobservable).

Pilihan investasi dimasa mendatang terkait dengan tingkat pertumbuhan perusahaan. Pertumbuhan perusahaan diharapkan akan memberikan aspek yang positif bagi perusahaan seperti adanya suatu kesempatan berinvestasi dimasa mendatang. Peluang pertumbuhan itu akan terlihat pada kesempatan investasi yang diproksikan dengan berbagai kombinasi nilai investment opportunity set. Perusahaan yang melakukan berbagai pilihan investasi memberikan sinyal bahwa perusahaan tersebut sedang dalam masa tumbuh.

Perusahaan yang sedang tumbuh tidak selalu perusahaan kecil yang sedang aktif melaksanakan kegiatan research dan development. Perusahaan kecil menghadapi keterbatasan pilihan dalam menentukan dan menjalankan proyek baru atau jika hendak merestrukturisasi aset yang ada. Perusahaan besar cenderung memiliki dominasi dalam merestrukturisasi pasar potensialnya (Gaver dan Gaver 1993). Perusahaan besar seringkali memiliki keunggulan kompetitif dalam 
mengeksplorasi kesempatan investasi yang muncul. Variasi pilihan-pilihan strategi perusahaan dalam rangka memperoleh keunggulan kompetitif serta perbedaan keputusan investasi yang diambil oleh perusahaan untuk menghadapi perusahaan pesaing yang hendak memasuki pasar mengakibatkan investment opportunity set (Gaver dan Gaver 1992).

Berbagai proksi IOS telah dipergunakan dalam banyak penelitian sebelumnya dan selalu menunjukkan bahwa selalu ada proksi IOS yang tidak dapat digunakan, sehingga belum ada kesepakatan tentang proksi yang dapat mewakili investment opportunity set secara tepat (Gaver dan Gaver 1993). Dalam penelitian ini proksi IOS menggunakan pengukuran nilai pasar perusahaan pada nilai buku aset (Smith dan Watss 1992; Amaech 2013; Gaver dan Gaver 1993; Smith Jr 1986; Zaharia 2012). Pengukuran pengukuran nilai pasar perusahaan pada nilai buku asset diukur dari persentase nilai perusahaan yang dihubungkan dengan asset-in-place. Semakin tinggi rasio ini mengindikasikan kurangnya ketergantungan pada aset dan semakin tinggi opsi pertumbuhan. Peluang pertumbuhan dan nilai pasar perusahaan pada nilai buku aset seharusnya berkorelasi positif. Perbedaan antara nilai buku dan pasar ekuitas akan terjadi karena peluang pertumbuhan di perusahaan (Anindita dan Prashant 2010), nilai pasar pada nilai buku ekuitas, mengukur nilai perusahaan sebagai proporsi peluang-peluang non pertumbuhan sehingga nilai pasar pada nilai buku ekuitas ini diharapkan akan meningkat seiring dengan meningkatnya peluangpeluang pertumbuhan.

\section{Investment Oportunity Set (IOS), Dividen dan Nilai Perusahaan}

Dividen adalah pembagian laba yang dibayarkan kepada pemegang saham berdasarkan pada banyaknya saham yang dimiliki. Keputusan dividen ditentukan dari jumlah keuntungan perusahaan setelah pajak. Dalam hal ini, keuntungan setelah pajak merupakan jumlah laba ditahan dan dividen yang akan dibagikan kepada pemegang saham. Oleh karena itu, keputusan dividen yang optimal didasarkan kepada tujuan memaksimalkan keuntungan yang dibagikan kepada pemegang saham dengan kendala memaksimalkan laba ditahan untuk diinvestasikan kembali (reinvestasi) sebagai sumber dana internal (Brav et al., 2005).

Kesempatan investasi yang dimaknai sebagai kombinasi antara asset-in-place dan pilihan investasi dimasa yang akan datang dengan net present value positif. Menurut Gaver dan Gaver (1993), kesempatan investasi merupakan nilai perusahaan yang besarnya tergantung pada pengeluaran-pengeluaran yang telah di tetapkan manajemen dimasa yang akan datang dimana pada saat ini masih merupakan pilihan pilihan investasi yang diharapkan akan menghasilkan return yang lebih besar. Sejalan dengan Smith dan Watts (1992) bahwa komponen nilai perusahaan merupakan hasil dari pilihan-pilihan investasi dimasa yang akan datang yang merupakan investment opportunity set (IOS). 
Kelompok peneliti yang mengatakan bahwa dividen berperan penting dalam proses penilaian perusahaan, mengungkapkan dua alasan, yakni konsep pertama, bird in hand yaitu bahwa dividen kas saat sekarang lebih berharga daripada kas masa depan yang diperoleh dari reinvestasi laba ditahan. Implikasinya bahwa investor lebih memerlukan pendapatan sekarang daripada pendapatan di masa mendatang dan selalu mencari saham-saham yang membayar dividen secara tetap dan menawarkan dividend yield yang tinggi. Pemegang saham ini akan khawatir ketika perusahaan mengurangi dividennya. Konsep kedua, informational content yaitu perusahaan yang membayarkan dividen memberi sinyal dan keyakinan kepada investor bahwa reinvestasi pendapatan akan menghasilkan dividen yang lebih tinggi secara substansial dimasa mendatang. Perubahan dalam kebijakan dividen akan memengaruhi sikap investor pada perusahaan yang akan berakibat pada harga pasar saham perusahaan (Gordon 1959 dalam Dhanani 2005). Berdasarkan uraian diatas maka diajukan hipotesis sebagai berikut.

H1: Kesempatan investasi (IOS) memediasi pengaruh dividen pay out ratio untuk meningkatkan nilai perusahaan.

Kebijakan pendanaan dan investasi merupakan bentuk kebijakan perusahaan yang bertujuan memaksimalkan nilai perusahaan. Perbedaan dalam pengambilan kebijakan ini didasarkan atas pandangan manajemen yang oportunistik. Rozeff (1982) dan Easterbrook (1984) menjelaskan bahwa pembayaran dividen mengurangi sumber-sumber dana yang dikendalikan oleh manajer, sehingga mengurangi kekuasaan manajer dan membuat pembayaran dividen. Hal ini serupa dengan monitoring capital market yang terjadi jika perusahaan memperoleh modal baru, sehingga mengurangi biaya keagenan.

Kebijakan pendanaan memerlukan kebijaksanaan manajer yang mampu menjelaskan variasi pengeluaran dan biaya dalam kebijakan pendanaan dan kebijakan dividen (Gaver dan Gaver 1995; Smith dan Watts 1991). Penelitian empiris mengenai tema ini telah banyak dilakukan di mana variabel-variabel utamanya terkait dengan IOS, dividen dan pendanaan. Keputusan mengenai leverage dan kebijakan dividend pay out telah menjadi fokus penelitian yang luas dan erat terkait dengan keputusan keuangan dan investasi.

Berdasarkan uraian di atas, teori keagenan memiliki relevansi untuk digunakan dalam upaya mengkaji hubungan kebijakan pendanaan dengan leverage dalam upaya menekan konflik kepentingan antara manajer dan pemegang saham. Manajer perlu memperbaiki kinerja perusahaan dan merespon positif kepentingan para pemegang saham melalui peningkatan investasi dengan tujuan menekan free cash flow, meningkatkan pembayaran dividen dan menggunakan hutang untuk kepentingan pendanaan perusahaan. Berdasarkan uraian diatas maka diajukan hipotesis sebagai berikut. 
H2: Kebijakan pendanaan berpengaruh positif terhadap kesempatan investasi (IOS).

Dalam upaya untuk mencapai tujuan perusahaan, manajer harus membuat keputusan investasi yang menghasilkan net present value positif (Fama 1978). Keputusan investasi tidak dapat diamati secara langsung. Jenis pengeluaran modal tampaknya berpengaruh besar terhadap nilai perusahaan, karena jenis informasi tersebut akan membawa informasi tentang pertumbuhan pendapatan yang diharapkan di masa yang akan datang. Mc Connel dan Muscarella (1984) menguji gagasan dalam kaitannya dengan tingkat pengeluaran research dan development perusahaan. Ternyata kenaikan dalam pengeluaran modal, relatif terhadap harapan-harapan sebelumnya, mengakibatkan kenaikan return atas saham sekitar waktu pengumuman, dan sebaliknya. Temuan tersebut telah membawa kepada suatu hasil yang menyatakan bahwa keputusan investasi yang dilakukan mengandung informasi yang berisi sinyal-sinyal akan prospek perusahaan di masa yang akan datang. Selanjutnya Chan et al. (1990) menemukan bahwa harga saham merespon positif pada pengumuman akan naiknya biaya research dan development. Prospek nilai perusahaan dapat ditaksir dari investment opportunity set (IOS). Berdasarkan uraian diatas maka diajukan hipotesis sebagai berikut.

H3: Kesempatan investasi (IOS) berpengaruh positif terhadap nilai perusahaan.

Beberapa penelitian (Baskin 1989; Amidu 2007; Bhaduri 2002; Tong dan Green 2005) menunjukkan bahwa pembayaran dividen berpengaruh positif terhadap tingkat leverage. Pembayaran dividen yang besar pada periode lampau akan meningkatkan kebutuhan kas dimasa datang dan mendorong dilakukannya peminjaman yang lebih besar dan mengarah pada rasio hutang yang tinggi. Penelitian Wahidahwati (2002) menunjukkan bahwa walaupun pembayaran dividen tidak memiliki pengaruh nyata pada rasio hutang, namun memiliki arah koefisien regresi yang negatif dengan rasio hutang. Penelitian tersebut konsisten dengan teori dan hasil penelitian Jensen et al. (1992), yang menyatakan pembayaran dividen muncul sebagai substitusi hutang di dalam struktur modal.

Pembayaran dividen memang dapat menurunkan persoalan keagenan, akan tetapi di sisi lain justru menimbulkan biaya. Biaya akan timbul karena jika perusahaan membayar dividen yang besar, aliran kas yang dihasilkan dari sumber internal tidak lagi layak untuk memenuhi kebutuhan investasi perusahaan. Hal ini mendorong perusahaan memenuhi kebutuhan dananya dari pihak eksternal.

Menurut Hasnawati (2005), keputusan investasi didefinisikan sebagai kombinasi antara aktiva yang dimiliki (assets in place) dan pilihan investasi di masa yang akan datang dengan net present value positif. Beberapa penelitian yang telah dilakukan sebelumnya (Myers 1977; Kallapur dan Trombley 1999, 2001; Gaver dan Gaver 1993; Smitt dan Watts 1992; Abed et al., 2011; Chen et al., 2000) menyatakan 
bahwa investment opportunity set (IOS) digunakan sebagai proksi keputusan investasi, karena keputusan investasi tidak dapat diamati secara langsung. IOS sebagai variabel laten tidak dapat diukur secara langsung, sehingga perlu dibentuk atau dikonfirmasi dengan berbagai variabel terukur. Keputusan investasi berdampak pada nilai pada saat diumumkan (McConnel dan Muscarella 1985). Berdasarkan uraian diatas maka diajukan hipotesis sebagai berikut.

H4: Kesempatan investasi akan memediasi kemampuan pembayaran dividen untuk meningkatkan nilai perusahaan.

\section{METODA PENELITIAN}

\section{Sampel dan Data}

Populasi dalam penelitian ini adalah seluruh perusahaan sektor manufaktur yang terdaftar di Bursa Efek Indonesia (BEI), dengan periode pengamatan mulai dari tahun 2008 sampai dengan tahun 2012. Adapun sampel yang digunakan dalam penelitian ini adalah menggunakan purposive sampling. Metoda purposive ini merupakan metoda pengambilan sampel dimana peneliti memiliki kriteria atau tujuan tertentu terhadap sampel yang akan diteliti. Adapun kriteria sampel yang digunakan dalam penelitian ini adalah, sebagai berikut: (1) perusahaan tersebut mempublikasikan laporan keuangan per 31 Desember untuk tahun buku 2008 sampai dengan tahun buku 2012; (2) perusahaan tersebut membagikan dividen. Sumber data dalam penelitian ini adalah data sekunder, yaitu data yang didapat dari pihak lain yang telah menghimpunnya terlebih dahulu. Sumber data yang digunakan terdiri dari Indonesian Capital Market Directory (ICMD), terbitan tahun 2008 sampai dengan tahun 2012.

Penelitian ini menggunakan path analysis untuk mengetahui dan menganalisis pengaruh dari variabel-variabel eksogen terhadap variabel-variabel endogen. Path analysis bertujuan untuk menerangkan akibat langsung dan tidak langsung dari seperangkat variabel, sebagai variabel penyebab, terhadap seperangkat variabel lainnya yang merupakan variabel akibat (Bahman 2012). Beberapa persyaratan yang harus dipenuhi dalam prosedur pengolahan data menggunakan path analysis dapat dikemukakan sebagai berikut: 1) hubungan antar variabel bersifat linier dan aditif; 2) semua variabel residu tidak saling berkorelasi; 3) pola hubungan antar variabel bersifat rekursif yaitu bahwa hubungan sebab akibat bersifat searah; tidak timbal balik dan 4) tingkat pengukuran semua variabel sekurang-kurangnya interval. Hair et al. (1998) menyatakan bahwa terdapat empat langkah yang harus ditempuh untuk menggunakan path analysis ini, yaitu: 1) mengembangan model, yang harus dilakukan berdasarkan teori; 2) mengembangan diagram jalur untuk menunjukkan hubungan kausalitas; 3) konversi diagram jalur ke dalam serangkaian persamaan struktural dan spesifikasi model pengukuran; dan 4) pemilihan matriks 
Tabel 2

Goodness of Fit Model Penelitian

\begin{tabular}{lccc}
\hline Goodness of Fit Indeks & Cut-off Value & Hasil & Keterangan \\
\hline Chi - Square & 14,067 & 8,547 & Fit \\
Probability & $\geq 0.05$ & 0,287 & Fit \\
CFI & $\geq 0.90$ & 0,996 & Fit \\
CMIN/DF & $<3$ & 1,221 & Fit \\
NFI & $\geq 0.90$ & 0,980 & Fit \\
GFI & $\geq 0.90$ & 0,984 & Fit \\
TLI & $\geq 0,95$ & 0,979 & Fit \\
AGFI & $\geq 0.90$ & 0,035 & Fit \\
RMSEA & $\leq 0.08$ & 0.033 & Fit \\
\hline Sumber:
\end{tabular}

Sumber: Data primer yang diolah

Penerimaan hipotesis nol menunjukkan bahwa model dapat diterima, hal ini juga dapat diperkuat dengan indeks-indeks goodness of fit lainnya seperti CFI (0,996), CMIN/DF (1,221), NFI (0,980), GFI (0,984), AGFI (0,035), RMSEA $(0,033)$ memberikan konfirmasi yang cukup kuat untuk dapat diterimanya model.

\section{Pengujian Hipotesis}

Berdasarkan perhitungan melalui analisis jalur yang mencakup variabel dividen $(D P R)$, pendanaan $(D A R)$, investment opportunity set (IOS) dan nilai perusahaan (Tobin's q). Maka tahap selanjutnya adalah menguji hipotesis yang diajukan, hasil uji hipotesis dapat dilihat berdasarkan besarnya critical ratio (c.r), probability dan standardized regression weight pada Tabel 2. Nilai critical ratio diatas 2,56 akan menghasilkan nilai estimasi yang signifikan pada taraf $(\alpha) 1$ persen sedangkan nilai critical rasio lebih besar dari 1,96 signifikan pada taraf $(\alpha) 5$ persen.

\section{Ringkasan Hasil Pengujian Hipotesis}

Untuk memudahkan dalam memberikan kesimpulan terhadap hasil penelitian ini disajikan ringkasan hasil pengujian untuk seluruh hipotesis pada tabel dibawah ini sebagai berikut:

Tabel 3

Ringkasan Hasil Pengujian Hipotesis

\begin{tabular}{lccc}
\hline \multicolumn{1}{c}{ Hipotesis } & $\begin{array}{c}\text { Tanda } \\
\text { Prediksi }\end{array}$ & $\begin{array}{c}\text { Koefisien } \\
\text { Regresi }\end{array}$ & Keterangan \\
\hline $\begin{array}{l}\text { H1 : Dividen berpengaruh positif terhadap kesempatan } \\
\text { investasi (IOS) }\end{array}$ & + & 0,488 & Diterima \\
H2 : Kebijakan pendanaan berpengaruh positif & + & 0,403 & Diterima \\
$\quad \begin{array}{l}\text { terhadap kesempatan investasi (IOS) } \\
\text { H3 : Kesempatan investasi (IOS) berpengaruh positif } \\
\quad \text { terhadap nilai perusahaan }\end{array}$ & + & 0.267 & Diterima \\
\hline Sumber: data primer yang diolah & & &
\end{tabular}




\section{Analisis Jalur}

Analisis jalur meneliti hubungan berbagai alternatif jalur variabel dari dividen, kebijakan pendanaan menuju nilai perusahaan. Analisis ini bertujuan untuk mencari jalur manakah yang paling berpengaruh terhadap hasil akhir dari penelitian ini. Alternatif jalur yang dimaksud terdiri dari dua alternatif. Berikut disajikan perhitungan berdasarkan standardized regression weight.

Tabel 4

Perhitungan Standardized Regression Weight Tiap Alternatif Jalur

\begin{tabular}{llr}
\hline \multicolumn{1}{c}{ Jalur } & \multicolumn{3}{l}{ Standardized Regression Weight } \\
\hline Dividen $\rightarrow$ IOS $\rightarrow$ Nilai Perusahaan & $(0,488)(0,267)$ & $=0,130296$ \\
Pendanaan $\rightarrow I O S \rightarrow$ Nilai Perusahaan & $(0,403)(0,267)=$ & 0,107601 \\
\hline
\end{tabular}

Berdasarkan perhitungan alternatif jalur diatas, angka jalur dividen $\rightarrow I O S \rightarrow$ nilai perusahaan adalah jalur yang memiliki nilai paling besar yang paling berpengaruh diantara jalur lainnya.

\section{PEMBAHASAN DAN SIMPULAN}

Penelitian ini bertujuan untuk menguji pengaruh kebijakan dividen dan pendanaan terhadap pilihan kesempatan investasi (IOS), dalam upaya penciptaan nilai perusahaan. Penelitian ini menawarkan solusi tunggal, dengan mengembangkan hasil sintesis dari kebijakan dividen dan pendanaan melalui variabel moderasi IOS. Hasil pengujian pada dugaan pertama mendapatkan dugaan empiris kebijakan pembayaran dividen berpengaruh secara positif dan signifikan terhadap kesempatan investasi (IOS). Penelitian ini mengindikasikan bahwa pembayaran dividen berpengaruh positif dan signifikan terhadap kesempatan investasi (IOS). Hal ini dapat dibuktikan dengan besarnya critical ratio sebesar 7,814.

Hasil penelitian mengenai peran pendanaan yang akan mendukung serangkaian kesempatan invetasi telah banyak menghasilkan simpulan yang beragam. Ada dua sumber pendanaan yang dapat dipilih oleh perusahaan yaitu dengan pendekatan teori pecking order dan trade off. Kedua pendekatan ini akan dipilih manajemen untuk membiayai berbagai kegiatan investasi yang diharapkan menghasilkan NPV positif. Dalam penelitian ini dugaan kedua memperoleh besarnya critical ratio sebesar 2,025 yang mengindikasikan kebijakan pendanaan berpengaruh secara positif dan signifikan terhadap kesempatan investasi (IOS).

Dalam berinvestasi perusahaan membutuhkan kesempatan, rencana atau proyek yang bisa dipilih untuk mewujudkan tujuannya menghasilkan NPV positif. Kesempatan investasi (IOS) ini akan memengaruhi investor dalam memandang perusahaan. Jadi IOS memegang peranan penting dalam menentukan strategi perusahaan. Kesempatan investasi yang dimiliki oleh perusahaan dipengaruhi oleh kelebihan dan keterbatasan yang dimiliki perusahaan. 
Kelebihan yang dimiliki perusahaan itu antara lain, profitabilitas dan ukuran perusahaan. Sedangkan keterbatasan perusahaan terdiri antara lain modal yang dimiliki perusahaan dan risiko yang dihadapi dalam bisnis. Dugaan ketiga dalam penelitian ini memperoleh critical ratio sebesar 0.390, yang mengidikasikan bahwa kesempatan investasi berpengaruh secara positif dan signifikan terhadap nilai perusahaan.

Serangkaian kesempatan investasi mampu memediasi kemampuan pembayaran dividen yang dilakukan perusahaan kepada pemegang saham untuk meningkatkan nilai perusahaan. Argumen ini dilandasi hasil studi Crutchley dan Hansen (1989) mengenai hubungan simultan antara kebijakan dividen dengan serangkaian kesempatan investasi (IOS) yang saling bersubstitusi dalam upaya menekan konflik keagenan. Demikian juga dilandasi dari hasil temuan Deshmukh (2005), Hennessy dan Whited (2005) serta Chen dan Strange (2006), bahwa masalah informasi asimetris atau konflik keagenan dapat dikurangi melalui mekanisme pembayaran dividen.

Deshmukh (2005) menunjukkan bukti bahwa dividen dipengaruhi oleh informasi asimetris dan biaya emisi saham. Mollah (2000) menunjukkan bukti bahwa kepemilikan manajerial yang mendorong pihak manajer untuk melakukan reinvestasi atas laba yang diperoleh akan menyebabkan manajer mengurangi atau tidak membayarkan dividen sama sekali. Dugaan keempat dalam penelitian ini dapat dijelaskan bahwa peran IOS secara signifikan sebagai mediator bagi keputusan dividen untuk meningkatkan nilai perusahaan yang terbukti pada nilai uji Sobel sebesar 1,9287 dengan $p$-value sama dengan 0,0322 yang berada dibawah 0,05. Hasil pengujian signifikan variabel mediasi memberikan sinyal akan pentingnya peran IOS untuk meningkatkan nilai perusahaan

Serangkaian kesempatan investasi memediasi pengaruh antara keputusan pendanaan untuk meningkatkan nilai perusahaan. Sejalan dengan konsep Gordon (1959) tentang dua alasan penting peran debt dalam proses peningkatan nilai perusahaan yang berimplikasi pada pertama, penggunaan debt untuk digunakan sebagai investasi guna memperoleh pendapatan di masa yang akan datang. Konsep kedua, informational content yang membuat debt sebagai sinyal dan keyakinan pada investor bahwa perusahaan melakukan investasi untuk meningkatkan pendapatan dimasa yang akan datang.

Ojah dan Manrique (2005) serta Chen dan Strange (2006) yang mendukung konsep agency cost memberikan bukti bahwa kebijakan dividen berpengaruh negatif terhadap debt rasio. Menurut teori pecking order, debt yang tinggi akan diakibatkan karena semakin banyaknya kebutuhan kas yang diperlukan untuk melakukan investasi perusahaan. Bila ketersediaan bagian kas di perusahaan tidak cukup memadai untuk kebutuhan untuk investasi, maka dana untuk investasi diperoleh dari hutang. 
Hasil uji signifikansi variabel mediasi dapat menjelaskan bahwa peran IOS secara signifikan sebagai mediator bagi keputusan pendanaan untuk meningkatkan nilai perusahaan yang terbukti pada nilai uji Sobel sebesar 1,7548765 dengan nilai $p$ value sama dengan 0,026522387 yang berada dibawah 0,05. Hasil pengujian signifikan variabel mediasi memberikan sinyal akan pentingnya peran IOS untuk meningkatkan nilai perusahaan.

\section{DAFTAR PUSTAKA}

Abed, S., S. Al-Okdeh, dan K. Nimer. 2011. The inclusion of forecasts in the narrative sections of annual reports and their association with firm characteristics: the case of Jordan. International Business Research. Vol.4 No.4.

Aharony, J., J. W. Wang, dan H. Q. Yuan. 2010. Tunneling as an incentive for earnings management during the IPO process in China. Journal of Accounting and Public Policy. Vol.29: 1-26.

Allen F., A. Bernardo, dan I. Weleh. 2000. A theory of dividend based on tax clienteles. Journal of Finance. Vol.55: 2499-2536.

Amidu, M. 2007. How does dividend policy affect performance of the firm on Ghana stock exchange. Investment Management \& Financial Innovations. Vol.4 No.2: 103-137.

Amihud, Y., dan B. Lev. 1981. Risk reduction as a managerial motive for conglomerate mergers. Bell Journal of Economic. Vol.12: 11-18.

Amaech, E. P. 2013. Application of computed financial ratios in fraud detection modelling: a study of selected banks in Nigeria. Asian Economic and Financial Review. Vol.3 No.11: 1405-1418.

Anindita, K., dan K. Prashant. 2010. Advertising and firm value: mapping the relationship between advertising, profitability and business strategy in India. M.A.N.K

Baskin, J. 1989. An empirical-investigation of the pecking order hypothesis. Financial Management. Vol.18: 26-35.

Bahman, B., dan M. Fakhroddin. 2012. Productivity and firm performance: Evidence of Iranian unprofitable firms. Australian Journal of Basic and Applied Sciences. Vol.6 No.7: 158-166.

Baker, M., dan J. Wurgler. 2004. A catering theory of dividend. Journal of Finance. Vol.38: 19-38.

Berle, A., dan G. Means. 1932. The Modern Corporation and Private Property. MacMillan, New York. 
Bhaduri, S. N. 2002. Determinants of capital structure choice: A study of the Indian corporate sector. Applied Financial Economics. Vol.12: 655-665.

Black, F., dan M. Scholes. 1973. The pricing of options and corporate liabilities. Journal of Political Economy. Vol.81 No.3: 637-659.

Brav, A., J. Graham, C. Harvey, dan R. Michaely. 2005. Payout policy in the 21st century. Journal of Financial Economics.

Chan, S. H., Martin, J. D., dan J. W. Kensinger. 1990. Corporate research and development expenditures and share value. Journal of Financial Economics. Vol.26 No.2: 255-276.

Chen, J., dan R. Strange. 2005. The determinants of capital structure: Evidence from Chinese listed companies. Economic Change and Restructing. Vol.38: 11-35.

Chen, S. S., K. W. Ho, C. F. Lee, dan G. H. H. Yeo. 2000. Investment opportunity, free cash flow and market reaction to international joint venture. Journal of Banking and Finance. Vol.24: 1747-1765.

Crutchley, C. E., dan R. Hansen. 1989. A test of agency theory of managerial ownership, corporate leverage, corporate dividends. Financial Management. Vol.18: 35-57.

Crutchley, C. E., M. R. H. Jensen, J. S. Jahera, dan J. E. Raymond. 1999. Agency problems and the simultaneity of financial decision making the role of institutional ownership. International Review of Financial Analysis. Vol.8 No.2: 177-197.

Deshmukh, S. 2005. The effect of asymmetric information and dividend policy. Quarterly Journal of Business and Economic Journal. Vol.44 No.1: 107-127.

DeAngelo, H., dan L. DeAngelo. 2006. The irrelevance of the MM dividend irrelevance theorem. Journal of Financial Economics. Vol.79: 293-315.

Dharmapala, D., dan V. Khanna. 2008. Corporate governance, enforcement, and firm value: evidence from India. Working Paper Series. No.8 Vol.5.

Easterbrook, F. H. 1984. Two agency-cost explanations of dividends. American Economic Review. Vol.74: 650-659.

Eskandari, A., dan F. O. Zadeh. 2012. A case study of examining and analyzing weighted average cost of capital. International Conference Turkey.

Fama, E. 1978. The effects a firm's investment and financing decisions on the welfare of its security holders. The American Economic. Vol.68 No.3: 272284.

Gordon, M. J. 1959. Dividen, earning and stock price. Review of Economics and Statistics (May): 99-105. 
Gaver, J. J., dan K. M. Gaver. 1993. Compensation policy and the investment opportunity set. Financial Management. Vol.24 No.1: 19-32.

Hasnawati. 2005. Dampak set peluang investasi terhadap nilai perusahaan publik di bursa efek Jakarta. Jurnal Akuntansi dan Auditing Indonesia. Vol.9 No.2: 117-126.

Hennessy, C. A., dan T. M. Whited. 2005. Debt dynamics. The Journal of Finance. Vol.60 No.3: 1129-1165.

Jensen, G. R., D. P. Solberg, dan T. S. Zorn. 1992. Simultaneous determination of insider ownership, debt, and dividend policies. Journal of Financial and Quantitative analysis. Vol.27: 274-263.

Jensen, M., dan W. Meckling. 1976. Theory of the firm: managerial behavior, agency, and ownership structure. Journal of Financial Economics. Vol.3 (October): 305-360.

Jensen, M. C., dan J. B. Warner. 1988. The distribution of power among corporate managers, shareholders, and directors. Journal of Financial Economics. Vol.20: 3-24.

Jiambalvo, J., dan S. Rajgopal. 2002. Institutional ownership and the extent to which stock prices reflect future earnings. Contemporary Accounting Research Vol.19 No.1: 117-145.

Kallapur, S., dan M. A. Trombley. 1999. The association between investment opportunity set proxies and realized growth. Journal of Business Finance \& Accounting. Vol.26 No.3: 505-519.

Khanna, T., dan K. Palepu. 1999. Policy shocks, market intermediaries, and corporate strategy: the evolution of business groups in Chile and India. Journal of Economics \& Management Strategy. Vol.8 No.2: 271-310.

Kole, S. 1991. An investigation of the building of compensation. Working Paper.

McConnel, J. J., dan C. J. Muscarella. 1985. Corporate capital expenditure decision and the market value of the firm. Journal of Financial Economic. Vol.14: 399-422.

Miller, M. H., dan F. Modigliani. 1961. Dividend policy, growth, and the valuation of shares. Journal of Business. Vol.34: 411-433.

Miller, R., dan F. Modigliani. 1961. Dividend policy, growth and the valuation of shares. Journal of Business. Vol.34 No.4 (October): 411-33.

Miller, M. H., dan M. Scholes. 1982. Dividends and taxes: some empirical evidence. Journal of Political Economy. Vol.90: 1118-1141.

Myers, S. C. 1977. Determinants of corporate borrowing. Journal of Financial Economics. Vol.5: 147-175. 
Mollah, A., K. K. Sabur, dan H. Short. 2000. The influence of agency costs on dividend policy in an emerging market: evidence from the Dhaka stock exchange. The Sixth ENBS Workshop at the University of Olso, Norway.

Ojah, K., dan J. Manrique. 2005. Determinants of corporate debt structure in a privately dominated debt market: a study of the Spanish capital market. Applied Financial Economics. Vol.15: 455-468.

Pawlina, G., dan L. Renneboog. 2005. Is investment-cash flow sensitivity caused by agency costs or asymmetric information? Evidence from the UK. European Financial Management. Vol.11 No.4: 483-513.

Rozeff, M. S. 1982. Growth, beta, and agency costs as determinants of dividend payout ratios. Journal of Financial Research. Vol.5: 249-259.

Smith, Jr., W. Clifford, dan R. L. Watts. 1992. The investment opportunity set and corporate financing, dividend, and compensation policies. Journal of Financial Economics. Vol.32: 263-292.

Smith Jr., C. W. 1986. Investment banking and the capital acquisition process. Journal of Financial Economics. Vol.15: 3-29.

Tong, G., dan C. J. Green. 2005. pecking order or trade-off hypothesis? Evidence on the capital structure of Chinese companies. Applied Economics. Vol.37: 2179-2189.

Wahidahwati. 2002. Kepemilikan manajerial dan agency conflict: Analisis persamaan simultan nonlinier dari kepemilikan manajerial, penerimaan risiko (risk taking), kebijakan utang dan kebijakan dividen. Simposium Nasional Akuntansi V. Ikatan Akuntansi Indonesia.

Zaharia, C. 2012. Corporate governance and the market value of firms. Economics, Management, and Financial Markets. Vol.7 No.4: 227-232. 